\title{
Correlation of Anaplastic Lymphoma Kinase Overexpression and the EML4-ALK Fusion Gene in Non-Small Cell Lung Cancer by Immunohistochemical Study
}

\author{
Tai-Di Chen, MD; Il-Chi Chang ${ }^{3}$, PhD; Hui-Ping Liu ${ }^{1,4}$, MD; Yi-Cheng Wu ${ }^{1}$, MD; \\ Chi-Liang Wang ${ }^{2}, \mathrm{MD}$; Ya-Ting Chen ${ }^{3}, \mathrm{MS}$; Yi-Rong Chen ${ }^{3}$, PhD; \\ Shiu-Feng Huang ${ }^{3}$, MD, PhD
}

Background: Recently the echinoderm microtubule-associated protein-like 4-anaplastic lymphoma kinase (EMLA-ALK) fusion gene with transforming activity was identified in non-small cell lung cancer (NSCLC). In addition, NSCLC patients with the EMLA-ALK fusion gene had a dramatic response and longer progression free survival after ALK inhibitor treatment than those without this fusion gene. However, the incidence and clinical and molecular characteristics of the EMLA-ALK fusion gene in NSCLC patients of Taiwan are still unclear.

Methods: Sixty-four fresh frozen tumor specimens were obtained from the tissue bank of Chang Gung Memorial Hospital for RNA extraction and EML4-ALK fusion gene detection. Paraffin sections of lung tumors from all of these patients were available and were analyzed for ALK protein expression by immunohistochemical (IHC) study. The results were correlated with clinical and molecular biomarkers.

Results: Three of the 64 tumors (4.7\%) had the EML4-ALK fusion gene. Two were adenocarcinomas, and one was adenosquamous carcinoma. Twenty patients with non-squamous cell carcinomas had epidermal growth factor receptor (EGFR) mutations, so the EML4-ALK fusion gene was found in $14.3 \%$ of $E G F R$ wild type non-squamous cell carcinomas. Two tumors were variant 3 $(3 a+3 b$ with $3 b$ predominant) and had strong staining (3+) for ALK by IHC stains. One tumor was variant 1 and had moderate staining (2+) for ALK. None of the $A L K$ wild type tumors had strong staining for ALK. When compared with other clinical and molecular features, only the IHC stain for ALK was significantly correlated with the EML4-ALK fusion gene $(p=0.0002)$.

Conclusions: ALK overexpression detected by IHC study could be a promising detection method for the EML4-ALK fusion gene and is worth further confirmation with more samples.

(Chang Gung Med J 2012;35:309-17)

Key words: NSCLC, EML4-ALK fusion gene, targeted therapy, ALK overexpression, immunohistochemical stain

T-D. Chen and I-C. Chang have equal contributions in this report.

From the Department of Pathology; 'Department of Cardiovascular and Thoracic Surgery; ${ }^{2}$ Division of Pulmonology, Department of Medicine, Chang Gung Memorial Hospital at Linko, Chang Gung University College of Medicine, Taoyuan, Taiwan; ${ }^{3}$ Division of Molecular and Genomic Medicine, National Health Research Institutes, Miaoli, Taiwan; ${ }^{4}$ Department of Thoracic Surgery, BenQ Medical Center, Nanjing, China

Received: Feb. 21, 2012; Accepted: April 20, 2012

Correspondence to: Dr. Shiu-Feng Huang, M.D., Ph.D. Department of Pathology, Chang Gung Memorial Hospital at Linkou. 5, Fusing St., Gueishan Township, Taoyuan County 333, Taiwan (R.O.C.) Tel: 886-3-3281200 ext. 8152 or 2509 ;

Fax: 886-37-586459; E-mail: sfhuang@nhri.org.tw 
$\mathrm{L}$ ung cancer is the leading cause of cancer death worldwide. ${ }^{(1)}$ Although there has been great improvement in the detection and treatment of lung cancer in the past 10 years, the overall 5-year survival rate remains low $(15 \%){ }^{(1,2)}$ The great success of the epidermal growth factor receptor (EGFR)-tyrosine kinase inhibitors (TKI), gefitinib and erlotinib, for treatment of lung adenocarcinoma has made targeted therapy an important therapeutic modality for major human cancers. ${ }^{(3,4)}$ Since the therapeutic responsiveness of EGFR-TKI is strongly associated with the presence of somatic EGFR mutations, genetic analyses of various molecular markers in tumor tissue have become standard laboratory tests for the clinical management of lung cancers. ${ }^{(5,6)}$

In 2007, Soda et al identified the fusion oncogene joining the echinoderm microtubule-associated protein-like-4 (EML4) and the anaplastic lymphoma kinase $(A L K)$ gene in non-small cell lung cancer (NSCLC). ${ }^{(7)}$ They also demonstrated the transforming ability of this fusion gene. ALK is a $200 \mathrm{kDa}$ receptor tyrosine kinase of the insulin receptor superfamily. Their signal pathway involves cell proliferation, differentiation, and anti-apoptosis. ${ }^{(7,8)} A L K$ translocation was first identified in anaplastic large cell lymphoma as nucleophosmin-ALK fusion protein resulting from chromosome rearrangement $\mathrm{t}(2 ; 5)(\mathrm{p} 23 ; \mathrm{q} 35) .{ }^{(9)}$ Various combinations of ALK with other proteins have subsequently been discovered. Almost all of the chimeric $A L K$ genes are derived from genomic breakpoints between exons 19 and 20, leading the fusion of the 3 '-end intracytoplasmic domain of $A L K$ with the 5 '-end dimerization domains from different partner proteins..$^{(10,11)}$ In vitro oncogenic experiments and in vivo mouse models have confirmed the oncogenic potential of $A L K$ fusion genes. ${ }^{(10,11)}$ Although ALK overexpression, point mutations and fusion proteins have been found associated with various neoplasms such as neuroblastoma, diffuse large B cell lymphoma, inflammatory myofibroblastic tumor, squamous cell carcinoma of the esophagus, and renal cell carcinoma, ${ }^{(12)}$ the $E M L 4-A L K$ fusion gene is unique to NSCLC. ${ }^{(13)}$ In addition, multiple $E M L 4-A L K$ variants in NSCLCs have been identified, and all of them could confer gain-of-function properties. ${ }^{(13)}$

Recently, the United States Food and Drug Administration (FDA) conditionally approved crizotinib (an ALK inhibitor) for treatment of NSCLC, after its efficacy and safety profile were confirmed in NSCLC patients with $A L K$ translocations in Phase I and Phase II trials. ${ }^{(14-16)}$ Thus, detection of the EML4$A L K$ fusion gene has become a an important new molecular marker for NSCLC patients.

An understanding of the epidemiology and the prevalence is necessary before developing a surveillance strategy in a defined population for a particular disease. Although several published reports have demonstrated that the incidence of the EML4-ALK fusion gene in NSCLC is usually low (1.5\% to $6.7 \%$ ), and more commonly found in adenocarcinoma and non-smokers, ${ }^{(7,13,17-20)}$ reports on the clinical and molecular characteristics of the EML4-ALK fusion gene in NSCLC patients in Taiwan are still quite rare. ${ }^{(21)}$ In this report, we detected the EML4$A L \mathrm{~K}$ fusion gene by reverse transcription-polymerase chain reaction (RT-PCR) in 64 NSCLC patients who had surgery at Chang Gung Memorial Hospital and correlated with ALK expression by immunohistochemical (IHC) study.

\section{METHODS}

\section{Patients and tissues}

Sixty-four fresh frozen tumor specimens from NSCLC patients receiving surgical resections at Chang Gung Memorial Hospital from May 2002 to April 2003 were obtained from the tissue bank of Chang Gung Memorial Hospital for RNA extraction and EML4-ALK fusion gene analyses. Signed informed consents were obtained. Paraffin sections of lung tumors from all of these patients were available for ALK protein expression analyses by IHC stain. The study protocol was reviewed and approved by the Institutional Review Board of Chang Gung Memorial Hospital.

\section{RNA extraction and complementary DNA syn- thesis}

Frozen lung cancer tissues of the 64 patients were used as starting materials for total RNA extraction by the Trizol method (Invitrogen, Carlsbad, CA, U.S.A.). Gel electrophoresis was performed to verify RNA quality. The resulting RNA was stored at $-80^{\circ} \mathrm{C}$ until complementary DNA was synthesized with the SuperScript First-Strand synthesis system (Invitrogen). 


\section{Reverse transcription-polymerase chain reac- tion for detection of different EML4-ALK vari- ants}

Based on published nucleotide sequences and reports, ${ }^{(7,19)}$ different primers were employed in the present study to identify different EMLA-ALK variants. Briefly, the primer set of Fusion-RT-S (5'GTGCAGTGTTTAGCATTCTTGGGG-3') and Fusion-RT-AS (5'-TCTTGCCAGCAAAGCAGTAGTTGG-3') was able to identify different variants by different base pairs (bp): variant 1 (247 bp), variant 4 (361 bp), variant 6 (316 bp) and variant 7 (385 bp). Variant 2 with 155 bp was identified by the primer set of Fusion 2-Genome-S (5'-AGCTACATCACACACCTTG ACTGG-3') and Fusion-GenomeAS (5'-AGCTTGCTCAGCTTGTACTCAGGG-3'). The primers E6A20-S (5'-TTCGAGCATCACCTTCTCC-3') and E6A20-AS (5'-GGACACCTGGCCTTCATAC-3') were used to detect variant 3 (3a: 482bp; 3b: 515 bp). For variant 5, V5b-S (5'GATATGGAGATCCAGGGAGGC-3') and FusionRT-AS were used and the resultant product was 231 bp. The condition of the thermal cycle in the polymerase chain reaction (PCR) was the same as in previous reports, ${ }^{(19)}$ If any PCR product with the expected size was obtained, nucleotide sequencing (Applied Biosystems PRISMR 3730 DNA Analyzer Sequencer Foster City, CA, U.S.A.) was performed. The resulting nucleotide sequences were verified by the Basic Local Alignment Search Tool (BLAST) program at National Center for Biotechnology Information to search for similar sequences.

\section{ALK protein expression analyses by IHC study}

An IHC stain using anti-ALK antibody (Invitrogen, Life Tech Corp) as the primary antibody was performed on the paraffin sections ( $5 \mu \mathrm{m}$ thick) of the 64 NSCLC patients. The detection used the Ventana Discovery XT staining system with the ultraView Universal DAB detection kit (Ventana Medical Systems, Inc, Tucson, AZ, U.S.A.). Deparaffinization was followed by $95^{\circ} \mathrm{C}$ antigen retrieval in commercial tris-base buffer with boric acid and ethylene-diamine-tetraacetic acid (Cell Conditioning 1, Roche, Rotkreuz, Switzerland) for 30 minutes. Then the slides were incubated with primary antibody (1:500) at room temperature overnight, followed by washing and detection according to the manufacturer's protocol. The IHC stains were evaluated by two pathologists (TD Chen and SF Huang) without knowing the results of the EML4-ALK fusion gene study. The IHC stains for ALK, when positive, always stained diffusely. Thus, the ALK stains were graded according to the intensity only. Tumors with weak staining were graded as $(1+)$; tumors with moderate staining were graded as $(2+)$; those with strong staining were grade as (3+), similar to previous studies. ${ }^{(22,23)}$

\section{EGFR and $K R A S$ mutation analyses}

The EGFR mutation analyses were performed by direct sequencing of the four coding sequences from exon 18 to 21. Kirsten ras oncogene (KRAS) mutation analyses were performed by direct sequencing of exons 2 and 3. The methodologies of the above 2 studies have been reported previously, ${ }^{(24,25)}$ The data of the EGFR and KRAS mutations in the 64 NSCLC patients have been included in our previously published reports. ${ }^{(24,25)}$

\section{Statistical analysis}

To analyze the differences in the major clinicopathological features correlated with ALK expression or the EMLA-ALK fusion gene, the frequencies and proportions were compared by the conventional chi-square association test or Fisher's exact test (when there was at least a cell frequency less than 5). A two-sided $p$ value less than 0.05 was considered statistically significant.

\section{RESULTS}

EML4-ALK fusion gene, and EGFR and KRAS mutations among the 64 NSCLC patients

Among the 64 NSCLC patients, there were 36 cases of adenocarcinoma, 23 of squamous cell carcinoma, 4 of adenosquamous carcinoma and one of large cell carcinoma. There were 3 tumors $(4.69 \%)$ with the EML4-ALK fusion gene. Two were adenocarcinoma with variant 3 (including both variants $3 \mathrm{a}$ and $3 \mathrm{~b}$, with $3 \mathrm{~b}$ predominant). One was adenosquamous carcinoma with variant 1 (Fig. 1). EGFR mutations were found in 20 patients, all with adenocarcinoma except for one with adenosquamous carcinoma. Eight (40\%) had L858R mutations and six (30\%) had exon 19 deletions. KRAS mutation was found in 2 patients, both with adenocarcinoma. None of these three types of mutations coexisted. After 
A. RT-PCR of EML4-ALK fusion RNA in NSCLC patients
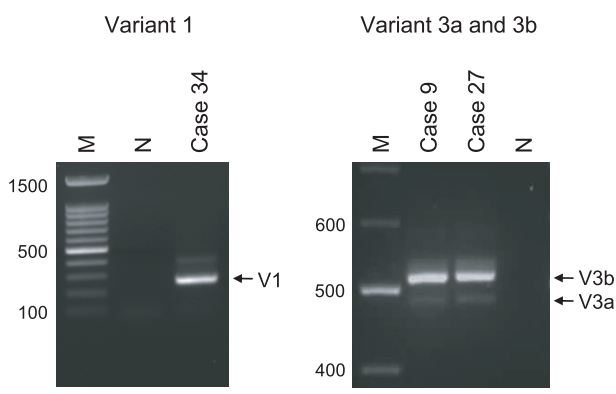

B. Chromatogram of variant 1 in case 34
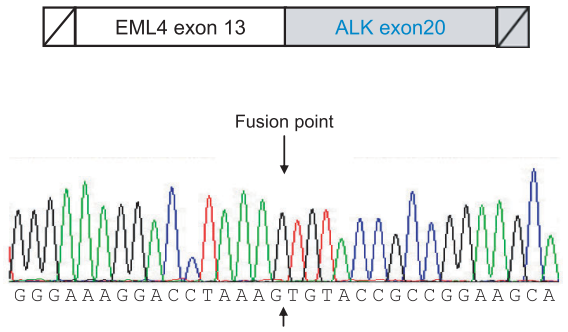

C. Chromatogram of variant $3 a$ and $3 b$ in case 9 and case 27

\begin{tabular}{|c|c|c|c|c|}
\hline 7 & EML4 exon $6 a$ & & ALK exon20 & Varient 3a \\
\hline 7 & EML4 exon $6 a$ & EML4 exon $6 b$ & ALK exon20 & Varient 3 \\
\hline
\end{tabular}

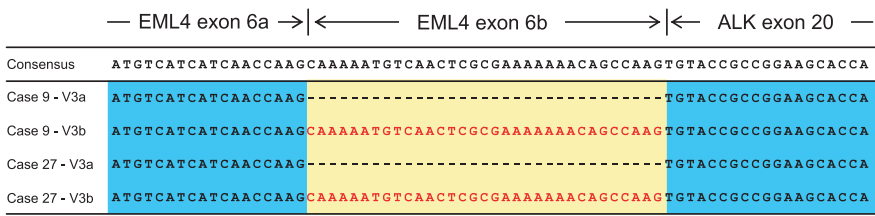

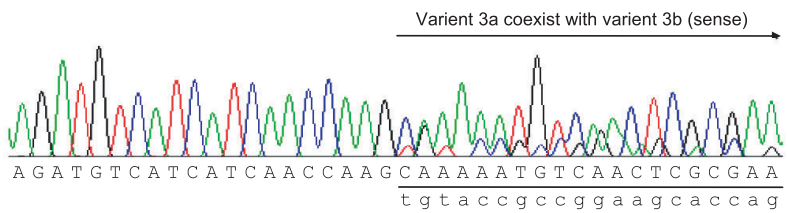

Varient 3a coexist with varient 3b (antisense)

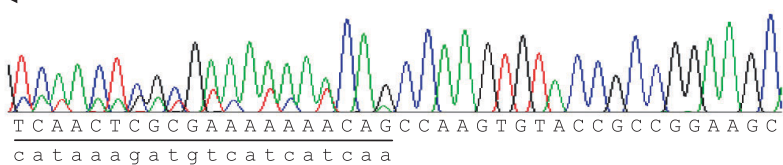

Fig. 1 EMLA-ALK translocation study using RT-PCR. (A) Gel electrophoresis reveals correct PCR product for variant 1 (patient 34) and variant 3 (Patients 9 and 27). Variant 3 demonstrates two PCR products, consistent with a dominant band of $3 \mathrm{~b}$ and a weaker band of 3a. (B) The chromatogram of Patient 34 with variant 1. (C) The chromatogram of Patients 9 and 27 with variant 3a and 3b. Abbreviations used: RT-PCR: reverse transcription-polymerase chain reaction; EML: echinoderm microtubule-associated protein-like; ALK: anaplastic lymphoma kinase; NSCLC: non-small cell lung cancer.

exclusion of patients with squamous cell carcinoma or EGFR mutation (+), the incidence of the EML4$A L K$ fusion gene was $14.3 \%$ (3/21) in patients with $E G F R$ wild type non-squamous cell carcinoma. The age, gender, smoking history, histology type, and tumor stage all had no significant associations with the EMLA-ALK fusion gene. The clinical and molecular characteristics associated with EML4-ALK translocation are summarized in the Table.

\section{ALK protein expression by IHC study}

Among the 64 tumors, 9 tumors were totally negative for ALK expression, and 46 tumors were weakly positive $(1+)$. Seven tumors were $2+$, and only 2 tumors were strongly positive (3+) (Fig. 2B and $2 \mathrm{C}$ ). All tumors with negative or weak staining for $\operatorname{ALK}(55 / 64,85.9 \%)$ had no EML4-ALK translocation. In contrast, both tumors strongly positive for
ALK were shown to harbor variant $3 \mathrm{a}+3 \mathrm{~b}$ transcripts of the EML4-ALK fusion gene. One of the seven tumors with moderate positive staining (2+) had the EML4-ALK fusion gene (variant 1). Thus, strong ALK IHC staining was the only variable that was significantly associated with the EMLA-ALK fusion gene $(p=0.0002)$. If we take IHC $2+$ as a cut-off value for positive ALK expression, the overall sensitivity and specificity of ALK IHC for detection of the EMLA-ALK fusion gene were $100 \%$ and $90.2 \%$. The positive and negative predictive values in unselected NSCLC patients were $33.3 \%$ and $100 \%$, respectively. After excluding 22 cases with EGFR or $K R A S$ mutations, the sensitivity and specificity of ALK IHC for detection of the EML4-ALK fusion gene were $100 \%$ and $94.9 \%$. The positive predictive value increased to $60 \%$. 
Table Clinical Characteristics of 64 NSCLC Patients

\begin{tabular}{|c|c|c|c|}
\hline Variables & $E M L 4-A L K(+)$ & $E M L 4-A L K(-)$ & $p$ value* \\
\hline Total number of patients & $3(4.69 \%)$ & $61(95.31 \%)$ & \\
\hline Gender & & & 0.5507 \\
\hline Male & $1(2.50 \%)$ & $39(97.50 \%)$ & \\
\hline Female & $2(8.33 \%)$ & $22(91.67 \%)$ & \\
\hline Median age (yr) (range) & $62.5(50-67)$ & $65(29-84)$ & $>0.9999$ \\
\hline$\leq 65 \mathrm{yr} / 0$ & $2(6.25 \%)$ & $30(93.75 \%)$ & \\
\hline$>65 \mathrm{yr} / 0$ & $1(3.13 \%)$ & $31(96.87 \%)$ & \\
\hline Smoking history & & & $>0.9999$ \\
\hline Never & $2(5.41 \%)$ & $35(94.59 \%)$ & \\
\hline Former & $1(3.70 \%)$ & $26(96.30 \%)$ & \\
\hline \multicolumn{4}{|l|}{ Histology type } \\
\hline Adenocarcinoma & 2 & 34 & \\
\hline Squamous cell carcinoma & $0(0.00 \%)$ & $23(100.00 \%)$ & \\
\hline Other $^{\dagger}$ & 1 & 4 & \\
\hline Stage & & & $>0.9999$ \\
\hline I + II & $2(5.56 \%)$ & $34(94.44 \%)$ & \\
\hline III + IV & $1(3.57 \%)$ & $27(96.43 \%)$ & \\
\hline ALK immunohistological stain & & & 0.0002 \\
\hline+ or - & $0(0.00 \%)$ & $55(100.00 \%)$ & \\
\hline++ & $1(14.29 \%)$ & $6(85.71 \%)$ & \\
\hline+++ & $2(100.00 \%)$ & $0(0.00 \%)$ & \\
\hline EGFR mutation & & & 0.5459 \\
\hline Mutant & $0(0.00 \%)$ & $20(100.00 \%)$ & \\
\hline Wild type & $3(6.81 \%)$ & $41(93.18 \%)$ & \\
\hline KRAS mutation & & & $>0.9999$ \\
\hline Mutant & $0(0.00 \%)$ & $2(100.00 \%)$ & \\
\hline Wild type & $3(4.84 \%)$ & $59(95.16 \%)$ & \\
\hline
\end{tabular}

Abbreviations: NSCLC: non small cell lung cancer; EMLA-ALK: echinoderm microtubule-associated protein-like 4- anaplastic lymphoma kinase; yr: year; EGFR: epidermal growth factor receptor; KRAS: Kirsten ras oncogene; *: Fisher exact test was used to compare each clinical parameter with fusion gene status; $\dagger$ : include 4 adenosquamous carcinoma and one large cell carcinoma.

\section{DISCUSSION}

In this study, the EML4-ALK fusion gene was found in 3 of the 64 NSCLCs (4.7\%) and in 14.3\% of 21 EGFR wild type non-squamous cell carcinoma. Both incidences were similar to previously published series, ${ }^{(7,13,17-20)}$ even though our case number was not large. The clinical and molecular characteristics shown in the Table also demonstrated features similar to those in previous reports in that none of the squamous cell carcinoma had the EMLA-ALK fusion gene and there were more non-smokers than smok- ers. All patients with the EMLA-ALK fusion gene had no co-existing EGFR or KRAS mutations. Although $E M L 4-A L K$ fusion gene variants 1 and 2 have been the main variants reported in the literature, two variant 3 and only one variant 1 were found in our series, similar to the reports by Koivunen et al. ${ }^{(17)}$ and Wong et al. from Hong Kong. ${ }^{(19)}$ They also found variant 3 to be the most common type in their patient group. Our incidence of the EML4-ALK fusion gene in NSCLCs (4.7\%) was also quite similar to Wong, et al $(4.9 \%)$. Wu et al. from Taiwan reported a very high incidence $(34 \%)$ of the EML4-ALK fusion gene in 

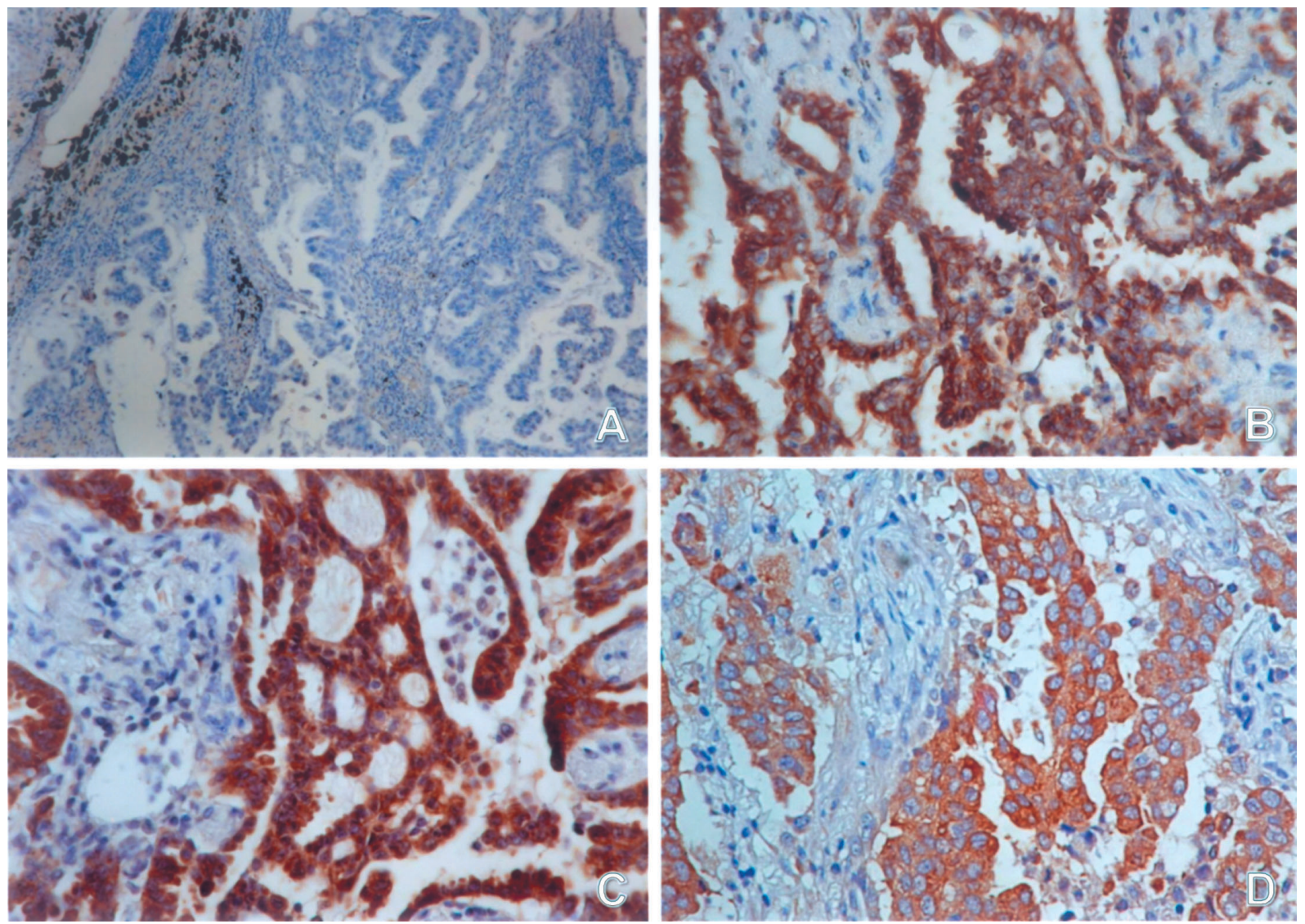

Fig. 2 ALK protein over expression detected by immunohistochemical stain in four adenocarcinoma patients. (A) Patient 17 with a totally negative stain for ALK. (B) Patient 7 with strong (3+) staining for ALK. (C) Patient 27 with strong (3+) stain for ALK. (D) Patient 34 with moderate staining (2+) for ALK (anti-ALK antibody, 200X). ALK: anaplastic lymphoma kinase.

adenocarcinoma patients with wild type EGFR. ${ }^{(21)}$ The above study only included adenocarcinoma patients with pleural effusions. Since their patients were a selected group, the data could not be compared with other published studies or the current report. One additional interesting finding in this study was that both patients with variant 3 had mixed $3 a+3 b$ with $3 b$ being predominant. We double checked this result. Currently, only 4 reports have mentioned variant $3 \mathrm{a}$ and $3 \mathrm{~b}$ of the EML4-ALK fusion gene. ${ }^{(13,17,18,21)}$ Among these, two papers mentioned the presence of variant 3 with mixed $3 a+3 b \cdot{ }^{(13,17)}$ In the report by Koivunen et al, ${ }^{(17)}$ four of the 8 tumors with $E M L 4-A L K$ translocation were variant 3 , two were variant 1 and two were variant 4 . All of their 4 tumors with variant 3 were mixed $3 a+3 b$ with $3 b$ being predominant, similar to our results.
In this study, the two tumors with strong ALK staining (3+) both had the EML4-ALK fusion gene (variant $3 a+3 b)$. One of the seven tumors with moderate staining (2+) had the EMLA-ALK fusion gene (variant 1). When compared with other clinical and molecular characteristics, ALK expression by IHC stain was the only variable that was significantly associated with the EML4-ALK fusion gene ( $p=$ 0.0002 ). If we use $2+$ as a cut-off value for positive ALK expression by IHC stain, the overall sensitivity and specificity of the ALK IHC for EML4-ALK fusion gene were $100 \%$ and $90.2 \%$. The above results suggest that ALK expression by IHC stain could be a good alternative screening method for detection of the EML4-ALK fusion gene when selecting NSCLC patients for ALK inhibitor treatment. This is an important issue, since RT-PCR for determination of the EML4-ALK fusion gene requires 
fresh tumor tissue for RNA extraction, which is often unavailable. Currently, break-apart fluorescence in situ hybridization (FISH) is the only conjunction test approved by the United States FDA to detect $A L K$ rearranged NSCLC. FISH assay is also the only validated test able to predict the response to crizotinib. ${ }^{(26)}$ However a reliable FISH assay requires technical expertise, and costs much more than an IHC stain. Detection of the EML4-ALK fusion gene by IHC stains could be a much easier and cheaper screening method for the EML4-ALK fusion gene in NSCLCs than break-apart FISH assay. Although a few published studies have demonstrated a good correlation between the ALK IHC method and FISH assay, ${ }^{(22,23,27,28)} 3$ of these 4 reports did not have data on the EML4-ALK fusion gene for direct comparison with the ALK IHC or FISH results, since they were unable to get tumor RNA samples. It is worth mentioning that in the only published report which directly compared the diagnostic accuracy among RT-PCR, FISH, and ALK IHC methods, only $60 \%$ of the cases were interpretable using FISH assay. ${ }^{(28)}$ Although FISH assay has been approved as the standard method for predicting ALK inhibitor response, a fundamental bias may stem from the low recovery rate of FISH assay on formalin-fixed paraffin embedded tissue. Correlation of IHC stain results with identification of the EMLA-ALK fusion gene by RTPCR and FISH assay in a larger number of NSCLC patients is warranted to draw a more confirmative conclusion. This will help to find the most costeffective method for determination of anti-ALK inhibitors usage in NSCLC patients in Taiwan.

\section{Acknowledgements}

This work was supported by grants from National Health Research Institutes (NHRI 96-A1MG-PP-04, NHRI-A1-MG-98-PP-04) and National Science Council (NSC97-2320-B-400-006-MY3), Taiwan.

\section{REFERENCES}

1. Jemal A, Bray F, Center MM, Ferlay J, Ward E, Forman D. Global cancer statistics. CA Cancer J Clin 2011;61:6990.

2. Jemal A, Siegel R, Ward E, Hao Y, Xu J, Murray T, Thun MJ. Cancer statistics, 2008. CA Cancer J Clin 2008;58: 71-96.

3. Mitsudomi T, Morita S, Yatabe Y, Negoro S, Okamoto I,
Tsurutani J, Seto T, Satouchi M, Tada H, Hirashima T, Asami K, Katakami N, Takada M, Yoshioka H, Shibata K, Kudoh S, Shimizu E, Saito H, Toyooka S, Nakagawa K, Fukuoka M; West Japan Oncology Group. Gefitinib versus cisplatin plus docetaxel in patients with non-small-cell lung cancer harbouring mutations of the epidermal growth factor receptor (WJTOG3405): an open label, randomised phase 3 trial. Lancet Oncol 2010;11:121-8.

4. Mok TS, Wu YL, Thongprasert S, Yang CH, Chu DT, Saijo N, Sunpaweravong P, Han B, Margono B, Ichinose Y, Nishiwaki Y, Ohe Y, Yang JJ, Chewaskulyong B, Jiang H, Duffield EL, Watkins CL, Armour AA, Fukuoka M. Gefitinib or carboplatin-paclitaxel in pulmonary adenocarcinoma. N Engl J Med 2009;361:947-57.

5. Maemondo M, Inoue A, Kobayashi K, Sugawara S, Oizumi S, Isobe H, Gemma A, Harada M, Yoshizawa H, Kinoshita I, Fujita Y, Okinaga S, Hirano H, Yoshimori K, Harada T, Ogura T, Ando M, Miyazawa H, Tanaka T, Saijo Y, Hagiwara K, Morita S, Nukiwa T; North-East Japan Study Group. Gefitinib or chemotherapy for nonsmall-cell lung cancer with mutated EGFR. N Engl J Med 2010;362:2380-8.

6. Ellis PM, Blais N, Soulieres D, Ionescu DN, Kashyap M, Liu G, Melosky B, Reiman T, Romeo P, Shepherd FA, Tsao MS, Leighl NB. A systematic review and Canadian consensus recommendations on the use of biomarkers in the treatment of non-small cell lung cancer. $\mathrm{J}$ Thorac Oncol 2011;6:1379-91.

7. Soda M, Choi YL, Enomoto M, Takada S, Yamashita Y, Ishikawa S, Fujiwara S, Watanabe H, Kurashina K, Hatanaka H, Bando M, Ohno S, Ishikawa Y, Aburatani H, Niki T, Sohara Y, Sugiyama Y, Mano H. Identification of the transforming EML4-ALK fusion gene in non-smallcell lung cancer. Nature 2007;448:561-6.

8. Chiarle R, Voena C, Ambrogio C, Piva R, Inghirami G. The anaplastic lymphoma kinase in the pathogenesis of cancer. Nat Rev Cancer 2008;8:11-23.

9. Palmer RH, Vernersson E, Grabbe C, Hallberg B. Anaplastic lymphoma kinase: signalling in development and disease. Biochem J 2009;420:345-61.

10. Bai RY, Dieter P, Peschel C, Morris SW, Duyster J. Nucleophosmin-anaplastic lymphoma kinase of large-cell anaplastic lymphoma is a constitutively active tyrosine kinase that utilizes phospholipase C-gamma to mediate its mitogenicity. Mol Cell Biol 1998;18:6951-61.

11. Chiarle R, Gong JZ, Guasparri I, Pesci A, Cai J, Liu J, Simmons WJ, Dhall G, Howes J, Piva R, Inghirami G. NPM-ALK transgenic mice spontaneously develop T-cell lymphomas and plasma cell tumors. Blood 2003;101: 1919-27.

12. Barreca A, Lasorsa E, Riera L, Machiorlatti R, Piva R, Ponzoni M, Kwee I, Bertoni F, Piccaluga PP, Pileri SA, Inghirami G; European T-Cell Lymphoma Study Group. Anaplastic lymphoma kinase in human cancer. J Mol Endocrinol 2011;47:R11-23. 
13. Choi YL, Takeuchi K, Soda M, Inamura K, Togashi Y, Hatano S, Enomoto M, Hamada T, Haruta H, Watanabe H, Kurashina K, Hatanaka H, Ueno T, Takada S, Yamashita Y, Sugiyama Y, Ishikawa Y, Mano H. Identification of novel isoforms of the EML4-ALK transforming gene in non-small cell lung cancer. Cancer Res 2008;68:4971-6.

14. Kwak EL, Bang YJ, Camidge DR, Shaw AT, Solomon B, Maki RG, Ou SH, Dezube BJ, Jänne PA, Costa DB, Varella-Garcia M, Kim WH, Lynch TJ, Fidias P, Stubbs H, Engelman JA, Sequist LV, Tan W, Gandhi L, MinoKenudson M, Wei GC, Shreeve SM, Ratain MJ, Settleman J, Christensen JG, Haber DA, Wilner K, Salgia R, Shapiro GI, Clark JW, Iafrate AJ. Anaplastic lymphoma kinase inhibition in non-small-cell lung cancer. $\mathrm{N}$ Engl J Med 2010;363:1693-703.

15. Camidge DR, Bang Y, Kwak EL, Shaw AT, Iafrate AJ, Maki RG, Solomon BJ, Ou SI, Salgia R, Wilner KD, Costa DB, Shapiro G, LoRusso P, Stephenson P, Tang Y, Ruffner K, Clark JW. Progression-free survival (PFS) from a phase I study of crizotinib (PF-02341066) in patients with ALK-positive non-small cell lung cancer (NSCLC). J Clin Oncol 2011;29 suppl:abstr 2501.

16. Crinò L, Kim D, Riely GJ, Janne PA, Blackhall FH, Camidge DR, Hirsh V, Mok T, Solomon BJ, Park K, Gadgeel SM, Martins R, Han J, De Pas TM, Bottomley A, Polli A, Petersen J, Tassell VR, Shaw AT. Initial phase II results with crizotinib in advanced ALK-positive nonsmall cell lung cancer (NSCLC): PROFILE 1005. J Clin Oncol 2011;29 suppl:abstr 7514.

17. Koivunen JP, Mermel C, Zejnullahu K, Murphy C, Lifshits E, Holmes AJ, Choi HG, Kim J, Chiang D, Thomas R, Lee J, Richards WG, Sugarbaker DJ, Ducko C, Lindeman N, Marcoux JP, Engelman JA, Gray NS, Lee C, Meyerson M, Jänne PA. EML4-ALK fusion gene and efficacy of an ALK kinase inhibitor in lung cancer. Clin Cancer Res 2008;14:4275-83.

18. Martelli MP, Sozzi G, Hernandez L, Pettirossi V, Navarro A, Conte D, Gasparini P, Perrone F, Modena P, Pastorino U, Carbone A, Fabbri A, Sidoni A, Nakamura S, Gambacorta M, Fernández PL, Ramirez J, Chan JK, Grigioni WF, Campo E, Pileri SA, Falini B. EML4-ALK rearrangement in non-small cell lung cancer and nontumor lung tissues. Am J Pathol 2009;174:661-70.

19. Wong DW, Leung EL, So KK, Tam IY, Sihoe AD, Cheng LC, Ho KK, Au JS, Chung LP, Wong MP; University of Hong Kong Lung Cancer Study Group. The EML4-ALK fusion gene is involved in various histologic types of lung cancers from nonsmokers with wild-type EGFR and KRAS. Cancer 2009;115:1723-33.
20. Paik JH, Choi CM, Kim H, Jang SJ, Choe G, Kim DK, Kim HJ, Yoon H, Lee CT, Jheon S, Choe JY, Chung JH. Clinicopathologic implication of ALK rearrangement in surgically resected lung cancer A proposal of diagnostic algorithm for ALK-rearranged adenocarcinoma. Lung Cancer 2012;76:403-9.

21. Wu SG, Kuo YW, Chang YL, Shih JY, Chen YH, Tsai MF, Yu CJ, Yang CH, Yang PC. EML4-ALK translocation predicts better outcome in lung adenocarcinoma patients with wild-type EGFR. J Thorac Oncol 2012;7: 98-104.

22. Yi ES, Boland JM, Maleszewski JJ, Roden AC, Oliveira AM, Aubry MC, Erickson-Johnson MR, Caron BL, Li Y, Tang H, Stoddard S, Wampfler J, Kulig K, Yang P. Correlation of IHC and FISH for ALK gene rearrangement in non-small cell lung carcinoma: IHC score algorithm for FISH. J Thorac Oncol 2011;6:459-65.

23. McLeer-Florin A, Moro-Sibilot D, Melis A, Salameire D, Lefebvre C, Ceccaldi F, de Fraipont F, Brambilla E, Lantuejoul S. Dual IHC and FISH testing for ALK gene rearrangement in lung adenocarcinomas in a routine practice: a French study. J Thorac Oncol 2012;7:348-54.

24. Huang SF, Liu HP, Li LH, Ku YC, Fu YN, Tsai HY, Chen YT, Lin YF, Chang WC, Kuo HP, Wu YC, Chen YR, Tsai SF. High frequency of epidermal growth factor receptor mutations with complex patterns in non-small cell lung cancers related to gefitinib responsiveness in Taiwan. Clin Cancer Res 2004;10:8195-203.

25. Wu CC, Hsu HY, Liu HP, Chang JW, Chen YT, Hsieh WY, Hsieh JJ, Hsieh MS, Chen YR, Huang SF. Reversed mutation rates of KRAS and EGFR genes in adenocarcinoma of the lung in Taiwan and their implications. Cancer 2008;113:3199-208.

26. Ou SH. Crizotinib: a novel and first-in-class multitargeted tyrosine kinase inhibitor for the treatment of anaplastic lymphoma kinase rearranged non-small cell lung cancer and beyond. Drug Des Devel Ther 2011;5:471-85.

27. Popat S, Gonzalez D, Min T, Swansbury J, Dainton M, Croud JG, Rice AJ, Nicholson AG. ALK translocation is associated with ALK immunoreactivity and extensive signet-ring morphology in primary lung adenocarcinoma. Lung Cancer 2012;75:300-5.

28. Just PA, Cazes A, Audebourg A, Cessot A, Pallier K, Danel C, Vacher-Lavenu MC, Laurent-Puig P, Terris B, Blons H. Histologic subtypes, immunohistochemistry, FISH or molecular screening for the accurate diagnosis of ALK-rearrangement in lung cancer: A comprehensive study of Caucasian non-smokers. Lung Cancer 2012;76: 309-15. 


\section{以免疫染色法研究未分化淋巴瘤活化酵素蛋白表現 與非小細胞肺癌之棘皮動物微管相關蛋白樣4-未分化淋巴瘤 活化酵素基因合併的相關性}

陳泰迪 張詣奇 ${ }^{3}$ 劉會平 ${ }^{1,4}$ 吴怡成 ${ }^{1}$ 王智亮 ${ }^{2}$ 陳雅婷 ${ }^{3}$ 陳怡榮 ${ }^{3}$ 黄秀芬 $^{3}$

背 景：未分化淋巴瘤活化酵素 $(A L K)$ 基因轉位, 尤其是棘皮動物微管相關蛋白樣4-未分化淋 巴瘤活化酵素基因合併 (EMLA-ALK fusion gene), 最近被發現在相當比例的非小細胞 癌肺癌中存在, 並與 ALK 抑制劑療效相關, 因此成爲新的重要腫瘤標的。在台灣族 群病患中, EML4-ALK 基因合併肺癌的臨床病理特徵, 尚未被探討研究過。何種檢驗 方法最爲適合於臨床上偵測 $E M L 4-A L K$ 基因合併, 目前亦尚未有定論。

方 法: 對 64 個非小細胞癌肺癌病患的檢體進行同步 ALK 免疫組織化學染色和 ALK 反轉 錄-PCR 檢測, 並分析臨床病理特徵與 $E M L 4-A L K$ 基因合併的關聯性。另外並檢測 EGFR 和 KRAS 基因突變，比較其和 EML4-ALK 基因合併的關聯性。

結 果：三例腫瘤具有 EML4-ALK 基因合併, 總發生率爲 4.69\% (3/64)。其中兩例有高度 ALK 蛋白過度表現 $(+++)$, 一例爲中度表現 $(++)$ 。免疫組織化學染色法偵測 ALK 蛋 白過度表現，相對於反轉錄 PCR 偵測 EML4-ALK 基因合併的敏感度可達 $100 \%$ ，而 特異性可達 $90.2 \%$ 。

結 論：ALK 免疫組織化學染色法偵測 EML4-ALK 基因合併有很好的敏感度和特異性, 可作 爲臨床上第一線偵測 EML4-ALK 基因合併的檢測方式，但仍需更多病例來證實。 (長庚醫誌 2012;35:309-17)

關鍵詞：非小細胞癌肺癌, EML4- $A L K$ 基因合併, 標靶療法, ALK 蛋白過度表現, 免疫組織 化學染色

陳泰迪及張詣奇並列第一作者。

長庚醫療財團法人林口長庚紀念醫院 解剖病理科, 1 心臟血管與胸腔外科, 2 胸腔內科; 長庚大學 醫學院; 3國家衛生研究 院 分子與基因醫學研究所; 4南京明基醫院 胸腔外科

受文日期：民國101年2月21日；接受刊載：民國101年4月20日

通訊作者 : 黃秀芬醫師, 長庚醫療財團法人林口長庚紀念醫院 解剖病理科。桃園縣333龜山鄉復興街5號。

Tel: (03)3281200轉8152或2509; Fax: (037)586459; E-mail: sfhuang@nhri.org.tw 